\title{
A NEED ANALYSIS IN ENGLISH FOR BUSINESS MATERIAL AT ECONOMIC FACULTY OF PANDANARAN UNIVERSITY
}

\author{
Tiara Nove Ria ${ }^{1}$, Djamaludin Malik ${ }^{2}$ \\ Management, Economic Faculty, Universitas Pandanaran, Central Java, Indonesia \\ tiaranoveria@unpand.ac.id \\ Management, Economic Faculty, Universitas Pandanaran, Central Java, Indonesia \\ malik_djamal@yahoo.co.id
}

\begin{abstract}
This study aims to find out what students' of Economics Faculty of Pandanaran University need in learning English for Business course to improve the materials design. Since in Indonesia so many companies have already engaged with overseas client or customer, they have already applied English as media for communication in their daily work. Then, for preparing the readiness of the graduates to work at such company, there is English for Business course that must be taken by the students of Economic Faculty. However, the materials which are taught to students, so far, do not meet the students' interest and need. That is why this study conducted to put the students first in improving materials. This quantitative and qualitative study used Needs Analysis Theory. Questionnaire and interview were conducted to collect the data and get all information to improve the materials design of English for Business Course. The participants of this study were an English lecturer, two HRD of multinational company, and 50 students of Economic Faculty at Universitas Pandanaran. The finding of this study shows several materials needed by students and it can be implemented in English for Business course.
\end{abstract}

Keywords: Need Analysis; English for Business; Material Design.

English in Indonesia still become a foreign language. However, the use of this language has already spread out in every level of society, communities and nations. It is used for communication with foreigners, doing business, diplomacy, and education. This is no excuse, whether it is really crucial or not, but nowadays many people in Indonesia use English for communication, actively or passively. For this reason, in the Economic Faculty of Pandanaran University required the students to learn English.
One of courses that require students' skill in English is implemented in English for Business. The goal of this course is in line with the visions of Economic Faculty that is preparing graduates who are nationally competitive in their career. At the end of the semester, after finishing this English for Business course, the students can implement the task of business in English at their work. However, the researcher found dissatisfaction due to the chosen of material. The researcher had conducted pre observation to several students who already 
work whether the use of tasks that needs English as the media of communication at work are in line with the materials being taught by the lecturer. They actually said not all materials used in their work environment.

Based on this pre observation finding, then the teacher realized that so far the syllabus and the material design was only based on lecturer's opinion only without knowing the students need as the learner.

English for Business is a part of English for Specific Purposes (ESP). According to (Basturkmen, 2006), the main purpose of ESP is to teach the language and communication skills that students need or will need to function effectively in their respective fields of study, work or profession. ESP is designed mostly towards professionals and seeks to focus on terminology used in a particular context. So students have the opportunity to master specific terms (Jeczelewski, 2016). The purpose of teaching ESP is for preparing students to the kind of English need that they will meet in their future profession (Mahardika, 2014). In conclusion, the ESP can be stated as teaching and learning English for using it in a specific domain. So this course establishes students for having good skills of English business in practical life.

The design of English language specifically ESP course needs to be prepared and identified well, so that the students as the learner can maximally get the goal. One of strategies to design effective course, especially in choosing the materials, is using need analysis. As stated by (Johns, Ann M., 2001) that in ESP course, a need analysis is a must. It aims to design the curriculum and the evaluation. In line with (Chunling, 2015), he said that the starting point of designing English for Business course is using need analysis. According to (Huh, 2006) the basis and valuable implication in developing curriculum and courses by the teacher was by conducting needs analysis.

There are some approaches in conducting need analysis. Based on Robinson in (Diana \& Mansur, 2018) recognize need analysis become Target Situation Analysis (TSA) and Present Situation Analysis (PSA). TSA focused on students' need while PSA focused on what students like to gain from the course, the strength, and the weakness of the students. Based on (Hutchinson, T., \& Waters, 1987), there are two terms which are classified into target needs and learning needs. Target needs means what the learners need to do in the target situation while learning needs means what the learners need to in order to learn.

A number of researchers on need analysis of ESP have been conducted. According to (Remache \& Ibrahim, 2018) in his research, the need analysis was suggested to use as a useful tool to design syllabus of Business English. In line with (Diana \& Mansur, 2018), she stated that in teaching English subject for ICT should provide the materials based on students' needs. The other research from (Khalik, 2014) proved that using students' based analysis in ESP teaching would determine the syllabus and material.

Identifying students' need can help the lecturer find the appropriate course material. Hence, the researcher want to conduct this research to find the best design of material needed in English for Business course that is fit for students of Economic Faculty at Universitas Pandanaran.

\section{METHOD}

This study used quantitative and qualitative research design. The data were collected through questionnaire and interview. The questioner was analyzed using quantitative analysis and the interview 
was analyzed using qualitative analysis. There were 50 students of Economic Faculty consist of Management and Accounting Major, an English lecturer and two HRD from PT Country Form Furniture and PT Holi Karya Sakti as the participants of this research. The questionnaires were given to students while the semi-structured interview was conducted to the lecturer and two HRD. The data collected from the analysis were combined to find out what material that students' need in English for Business Course.

\section{FINDINGS}

In this research, the data for learning needs was taken from the 50 students and the lecturer while the data for target needs was taken from two HRD. The data obtained from the questionnaire was divided into three sections. They were students' personal information, students' need for learning English for business and the materials' need by students to be taught.

The first section was asked about students' personal information. The respondents were selected from 50 students of Economic Faculty that already finished their General English in the previous semester. The detail information can be seen in table 1.

Table 1. Students' Personal Information

\begin{tabular}{|l|l|l|l|l|l|}
\hline \multicolumn{2}{|l|}{ Gender } & \multicolumn{2}{|l|}{ Age } & \multicolumn{2}{|l|}{$\begin{array}{l}\text { Level of } \\
\text { English } \\
\text { Proficiency }\end{array}$} \\
\hline Male & 16 & $19-21$ & 23 & Poor & 6 \\
\hline Female & 34 & $22-24$ & 17 & Fair & 36 \\
\hline & & $\begin{array}{l}25 \\
\text { and } \\
\text { above }\end{array}$ & 10 & Good & 7 \\
\hline & & & & $\begin{array}{l}\text { Very } \\
\text { Good }\end{array}$ & 1 \\
\hline
\end{tabular}

Source: Students' Questionnaires
The next section, there were three questions asked to students. The first was about students' need in learning English for Business. There were $62 \%$ of students stated strongly agree that English for Business was needed for their performance at work, $36 \%$ of students agree that and only $2 \%$ of student stated that English is not helpful at their performing at work.

The second was about English language skills that need to be emphasized in every implementation of learning English for Business to support the students for their future work. There are four English skills that the students' want to be emphasized here, speaking, writing, listening and reading. There were $88 \%$ of students chose speaking skill was needed to emphasize. The next was writing which $66 \%$ of students stated that this skill needed to be taught. For listening skill, there was $60 \%$ of students need this skill to be emphasized. The last skill was reading, only $50 \%$ needed this skill to be learnt.

In the third question, students were asked the needs of additional hours for English for Business course. From 50 students, there were $30 \%$ strongly agreed and $58 \%$ agreed that the course should be additional time. It means the credit point should be added.

The last section asked in the questionnaire was about the material needed by the students that will be given by the objectives needed. The students were given a list of objectives needed which they were asked to rank. The scales were "Essential Priority", "High Priority", "Medium Priority", "Low Priority", and the last "Not a Priority". The list of objectives was 18 (eighteen).

Table 2. Course Objectives

Course Objective Mean 


\begin{tabular}{|l|c|}
\hline \multicolumn{1}{|c|}{ Course Objective } & Mean \\
\hline To do business presentations & 3.6857 \\
\hline $\begin{array}{l}\text { To understand spoken work- } \\
\text { related instruction }\end{array}$ & 3.6571 \\
\hline $\begin{array}{l}\text { To express opinions at business } \\
\text { meetings }\end{array}$ & 3.5857 \\
\hline $\begin{array}{l}\text { To write a job application letter } \\
\text { and personal data }\end{array}$ & 3.5714 \\
\hline To negotiate & 3.5714 \\
\hline $\begin{array}{l}\text { To conduct business } \\
\text { conversations over the phone }\end{array}$ & 3.5571 \\
\hline To write business email & 3.5571 \\
\hline To conduct job interviews & 3.5429 \\
\hline To write business letters & 3.5286 \\
\hline To serve customers orally & 3.4571 \\
\hline $\begin{array}{l}\text { To write contract / agreement } \\
\text { documents }\end{array}$ & 3.4571 \\
\hline $\begin{array}{l}\text { To write report documents } \\
\text { (meetings / sales / finance, etc.) }\end{array}$ & 3.4286 \\
\hline To read email & 3.4143 \\
\hline To read work-related literature & 3.4143 \\
\hline $\begin{array}{l}\text { To read contract / agreement } \\
\text { documents }\end{array}$ & 3.4000 \\
\hline To read business letters & 3.3857 \\
\hline $\begin{array}{l}\text { To write proposals (projects, } \\
\text { plans, etc.) }\end{array}$ & 3.3714 \\
\hline $\begin{array}{l}\text { To understand written work- } \\
\text { related instructions }\end{array}$ & 3.3286 \\
\hline Source: Students' Questonnaires \\
\hline To
\end{tabular}

Source: Students' Questionnaires

The next data was obtained from the English lecturer who supports the data from the previous result. The lecturer was interviewed using semi-structured interviews. There were three questions for the lecturer including the purpose of teaching English for business for the students, how the teacher design the materials and what should be taught for them in English for Business course.

The result on the interview, it was found that the lecturer taught English for Business course because the Head of Department asked her. After that, the lecturer herself tried to find the goal of the course and the design of the materials. The lecturer designed the material based on her own opinion that she got from any sources. Based on the lecturers highlighted, the four English skills have to be taught especially speaking and writing.

The next data was from the target needs which were two HRD from PT. Country Form Furniture and PT. Holi Karya Sakti. PT. Country Form Furniture is a company located in Kawasan Industri Tugu Wijaya Kendal. The company is an international exporter design company that serves furniture and decorative elements. The second company is Gloves, Accessories Manufacturer \& Exporter Company that is located in Grobogan Semarang. Both company are exporters, which serve international customer. The two participants were interviewed also using semi-structured interviews.

Based on the interview, the researcher got the data about what English often used by their staff at their task work. The skills are writing, speaking, reading and listening. Actually writing skill was the first high priority that the staff should be mastered because the communication often did with their customer through email but spoken activity also become the priority because the customer sometimes need to talk directly by phone, video call or directly come to the company. In other hand, the ability of reading and listening automatically must be possessed by staffs because these abilities are needed to support speaking and writing skills.

The tasks that often did by the staff were writing reports, emails, letters, and sometimes talk to the customer through telephone. Other tasks were presentation products, how to negotiate, serve the customers' complain through email, 
telephone, or sometimes directly. Regarding job application, the HRD of PT. Country Form requires the applicant to send a job application letter and CV in English. In other hand PT. Holi Karya viewed this requirement as added value of the applicant. However, both of these companies conduct interviews in English in selecting their staffs.

\section{DISCUSSION}

Analysis need is needed in ESP because as lecturer can really know what students need and wants effectively. Based on (Hutchinson, T., \& Waters, 1987), two model approach in conducting need analysis which are target needs and learning needs. Target needs means what the learners need to do in the target situation while learning needs means what the learners need to in order to learn.

The target need is related to the ability of the students that should be mastered so that they will be able to perform the task at work while learning needs is related to the learning situation to facilitate students reach the target. These two model should be combined for doing need analysis (Mahardika, 2014) so it can be completed information of each other. Then, in this research these two approaches used. The target needs here were two HRD of multinational company and the learning needs were 50 students and an English lecturer.

As English for Business is one of English for Specific Purposes that the goal is to mastering specific terms (Jeczelewski, 2016), it was in line with the students reaction in the first result of this research when they were given a statement "The English for Business courses provided support your English language skills in your perform at work". There were $62 \%$ strongly agree and $36 \%$ agree with the statement. It indicates that the students already know and they were aware the purpose of the course in their future work.

This students' result was also in line with the lecturer statement that the goal of the course should be for preparing the students become ready to practice the knowledge in their task of their future work. It must be different from General English course that is taught specifically on English skills for everyday life.

The students' need result above is also agreed by the target need which is HRD of two companies. They do agree that English for Business is really needed to be taught to students because it is used at the company which the work environment is using English. It was not only General English but also specifically English that was practically support the work. English skill does not become priority skills when the staffs enroll the job but it is important to have this skill to support their work.

The next result is about students' need in learning English skills. The result of this step will be basis for designing the materials needed. As mentioned above, students stated that speaking skill must have more concern to be learnt. According to (Liton, 2015), Business English course are needed to improve communication skills which can later be used to help with workplace performance and create new career opportunities. Based on this statement, the students' answer indicates students are already aware of the importance of mastering this skill for the task in their future work. According to the interview result with two HRD, they also agree that speaking skill becomes priority for their staff. This speaking skill helps their staff to serve the customers when dealing with purchasing of a product, claim, negotiate with a new customer, meeting with the owner, selling the product directly to customers that come 
to the company or through telephone or video call like Skype because the direct activities have already decreased due to the use of social media.

The second rank of students' need to

$\ll \mid 72$ be emphasized is writing. This prioritize showed that students are already aware about the use of writing at work. As stated by Marcellino in (Milaningrum et al., 2018), writing is the important need to be learnt by the students because this skill is not only used in academic practice but also for their future work. Therefore, this skill must be learnt effectively. This is in line with the lecturer that also makes this skill become the second prioritize to be taught to students. The materials such as writing kind of documents and email have been delivered to the students after the students learn spoken activities.

The activities related to writing ability at work, based on HRD information including writing email, letters, sales report, and documents. HRD of PT. Holi Karya said that more than $50 \%$ of activities in certain job such as purchasing division, export import divisions are done through email. This writing ability actually becomes the most priority used in both company.

The third need is listening skill. From the result, it indicates that students know about the need of listening skills for their future work. It is supported by (Gray \& Murray, 2011) who stated in their study that listening skill in the business is highly priority element in the task work. Though this skill was the third of students' choice, it is still been chosen by them to be learnt. The listening skill must be mastered well because it supports the staffs to understand any spoken activities. Based on HRD of PT. Country Form, the lack of listening skill causes misunderstanding and leads to dissatisfaction from the customer. It is clearly detrimental to the company.

The last skill is reading. This indicates that the students are unaware with the importance of reading skills. Reading skill is needed too at the workplace such as to understanding the newest knowledge related to the job field, understanding the documents which sent to the company, business letters, and reports in English. As what (Remache \& Ibrahim, 2018) said in his study that this skills must be improve because it can help them face their future career.

Based on the result showed above about materials that needed for the task at work, the students given lists of course objective to guide the lecture design the materials to teach in each meeting. The students were asked to rank of each course objective based on their priority. The design of materials is based on the high rank to lower rank of students' needs of objective course. The students' priority of objective course was the same with the needs of skills that want to be emphasized in English for Business course. The high ranks of the objective are mostly to be able to do spoken tasks that are needed at work. However, the other skills should be arranged proportionally.

The course objective can be the guidance to decide the topic. As what (Remache \& Ibrahim, 2018) concluded in their study, that this was an opportunity for the lecturer to design better materials that meet the students' language need. The materials needed are Doing Presentation, Understanding Instruction at work, Conducting Business Meeting, Creating Application Letter and CV, Negotiation, Telephoning, Business Email, Doing a Good Job Interview, Creating Interesting Business Letter, How to Serve Customer, Knowing 
Document at Work, Reading Kind of Literature about Business, Writing Proposal.

\section{CONCLUSION}

Based on the research, it is showed that need analysis can get important result in designing materials for English for Business course. By knowing the students need of skills, lecturer can focus on the teaching and learning process. It is because the design based on the students' needs, want, desires and expectations. This research also brings the fits of material that not only needs by learning needs but also the target needs. That is way, the need for English for Business course and materials can be useful to use.
The result showed that the skills need to be learnt are speaking, writing, listening and reading. The first and second choices skills match with what is needed by target needs though the other skills are so important to be learnt to support speaking and writing skills.

\section{Acknowledgments}

The researchers want to express their special thanks to the Directorate of Research and Community

Service (DRPM) Kemenristekdikti who has funded this research with the scheme of Hibah Penelitian Dosen Pemula in the 2020 budget hence the research can be completed well.

\section{REFERENCES}

Basturkmen, H. (2006). Ideas and Options in English for Specific Purposes. Lawrence Erlbaum Associates, Inc., Publishers.

Chunling, G. (2015). Need Analysis and Curriculum Design in Business English. Studies in English Language Teaching, 3(2), 146. https://doi.org/10.22158/selt.v3n2p146

Diana, S., \& Mansur, M. (2018). Need Analysis on English Teaching Materials for Ict Students. ETERNAL (English, Teaching, Learning, and Research Journal), 4(2), 209. https://doi.org/10.24252/eternal.v42.2018.a6

Gray, F. E., \& Murray, N. (2011). A distinguishing factor: Oral Communication Skills in New $\begin{array}{lll}\text { Accountancy } & \text { Graduates. November } & \end{array}$ https://doi.org/10.1080/09639284.2011.560763

Huh, S. (2006). A task-based needs analysis for a Business English course. Second Language Studies, 24(2), 1-64.

Hutchinson, T., \& Waters, A. (1987). English_for_specific_purposes_hutchinson.pdf. Cambridge University Press.

Jeczelewski, S. (University of I. (2016). Needs Analysis, Course Design and Evaluation of Business English. BA Research Project, University of Iceland School of Humanities Department of English, May, 28.

Johns, Ann M., D. P.-M. (2001). English for Specific Purposes: Tailoring Courses to Student Needs - and to the Outside World. In M. Celce-Murcia (Ed.), Teaching English as a Second or Foreign Language (Third-Edit, p. 49). Heinle\&Heinle.

Khalik, L. A. (2014). ESP needa Analysis Based Syllabus Of Economics FacultyStudents, Universitas “ 45 ” Makassar. The Second International Conference on Education and Language, 116-127.

Liton, H. A. (2015). ESP learners' needs related learning for the workplace: A pragmatic study for business school. International Journal of Instruction, 8(2), 4-16. 
https://doi.org/10.12973/iji.2015.821a

Mahardika, A. . N. Y. M. (2014). The Need for Needs Analysis in Curriculum Development in ESP Course : a Reflection on Curriculum Development in Indonesia. Lingua Scientia, 6(2), 183-194.

Milaningrum, E., Damayanti, L., \& Gafur, A. (2018). the Impact of Guided Writing «|74 Technique To Develop Students' Esp Writing Skills in Balikpapan State Polytechnic. 1, 98-110. https://doi.org/10.24127/pj.v7i1

Remache, A., \& Ibrahim, M. K. (2018). Business English Syllabus Design: Putting Students Needs First. International Journal of English Language and Literature Studies, 7(4), 81-93. https://doi.org/10.18488/journal.23.2018.74.81.93 